\title{
Carl Schmitt's Sovereign: A Critique
}

\author{
YING KHAI LIEW
}

\begin{abstract}
The discussion of the sovereign is a discourse of legal limits - the boundary between law and non-law. Steering clear from providing an abstract definition, Carl Schmitt bases his discussion on the concrete application of the sovereign. This short article considers the viability of Schmitt's theory and his attempt to "secularise theological concepts" by exploring three aspects of the theory: the pouvoir constituant, the "dialogue" between the nation and the sovereign, and the "decision" of the sovereign. The paper concludes that Schmitt's sovereign does not convincingly overcome the inherent dissonance between the transcendental and the temporal.
\end{abstract}

\section{I: INTRODUCTION}

The discussion of the sovereign is a discourse of legal limits. Being at the "outermost sphere" (Schmitt 1985, 5) of legal power, the sovereign (if he indeed exists) occupies the boundary between law and non-law. For Carl Schmitt, this is not merely an objective position, but also one with a practical relevance. Since "[a]11 significant concepts of the modern theory of the state are secularized theological concepts" (Schmitt 1985, 36), Schmitt has to cope with the dialectics and paradoxes common to theological discourse. While the theologian may well attribute abstract conceptions to the omnipotent God, Schmitt's secularised version purports to go a step further by grounding his conception on a "concrete application".

\section{II: SCHMITT'S THEORY: AN OVERVIEW}

At the heart of Schmitt's theory lies his unique approach to dialectics, best expressed in the words he quotes from Kierkegaard: "[ $t]$ he exception explains the general and itself" (Schmitt 1985, 15). Thus, Schmitt $(1985,5)$ famously declared that the "sovereign is he who decides on the exception". For him, dictatorship is a "state of exception" - a transitional, exceptional suspension of the norms of the state. In the exception, there arises the possibility of a contradiction between "governance" and "actualisation"; between "norms" and "decisions". A distinction is made between "commissarial dictatorship" and "sovereign dictatorship", the latter being the description of the sovereign's decision in the state of exception. The "fusion" between the two is effected by the pouvoir constituant - the constituting power of the people. In identifying himself with the Hobbseian "natural law of science" tradition, Schmitt is not concerned about the content of decisions, but with the fact that a decision is 
taken at all.

\section{III: CRITIQUE}

In answering the difficult question "What is sovereignty?", Schmitt $(1985,6)$ states that "it really does not matter whether an abstract scheme advanced to define sovereignty... is acceptable... What is argued about is the concrete application". As such, the viability of his theory must ultimately be measured against the extent to which the conception is of concrete relevance.

\section{a) The pouvoir constituant and the unity of the "nation"}

The pouvoir constituant is that which allows the sovereign to remain "legal" in the state of exception. Since it is itself non-constituted, it crucially remains the justificatory power even when the entire existing constitution is suspended. From a theoretical point of view, the omnipotence of the pouvoir constituant plays the theological role of the "objectively unclear" God (Schmitt 1994, 140): it acts as the extra-legal power which justifies the legal power of the sovereign. This is conceptually attractive in that it provides a rational, comprehendible substitute for the non-constituted, constituting authority of God.

However, doubts arise as to the success of Schmitt's attempt to translate this secularised concept into concrete actuality. The concept finds its root in Rousseau's "volonté générale" — the will of the state. In Verfassungslehre, Schmitt $(1928,79)$ refines this will as emanating from the "nation" - "the people as a unity capable of political action" (emphasis added). Compare this perceived "unity" with any concrete populace. A nation is made up of individuals. The question, then, is whether there exists a concrete, normatively neutral common denominator which in fact unites the individual wills of the people. Now, one might think that Rousseau's concept of the vertu provides this common denominator, since it prevails even where the true will of the majority is suppressed by egoistic affects (Schmitt 1994, 120). However, it seems that Schmitt saw the vertu only as a justification to his concept of sovereignty, since dictatorship corrects the disunity of vertu - that is, "to help the egoist, who is not free, to find his true will" (Schmitt 1994, 121). It would be contradictory if the unity of the vertu were taken as both the aim and the source of the sovereign's power.

It appears that Schmitt simply takes "the relative homogeneity of the people" as "factually given" (Böckenförde 1986, 42). However, without demonstrating what actually unites the individual wills of the people, he seems to have merely hypostasised the abstract idea of "the general will", in order to claim the concrete relevance of the sovereign. If Schmitt $(1994,134)$ only "assume [s] the existence of a power" (emphasis added) - i.e. the pouvoir constituant, then he only goes so far as to show that such a justifying power ought to exist, and ought to justify the sovereign; he does not yet show the concrete "is"-fact from which this justification emanates. If this criticism holds true, then Schmitt's conception does not really explain "[h]ow...a legal order [is] possible in the first place" (Delacroix 2005, 32) - he does not go 
further than Kelsen did. Indeed, both jurists presuppose a unity; the difference being only that Kelsen's unity applies to the entire legal order, whereas Schmitt's applies to the pouvoir constituant. But while Kelsen is up-front about the fact that this unity is a presupposition, Schmitt seems to have hidden it behind the hypostasis that such a unity does in fact exist. Indeed, by assuming the unity of will, the pouvoir constituant fails to break free from one of the tropes of Agrippa's Trilemma.

\section{b) The dialogue between the nation and the sovereign}

To ground the concept in concrete actuality, Schmitt builds his theory upon Sieyès' notion of "permissibility of representation". At the core of this idea lies an interesting two-way "dialogue" between the "nation" and the sovereign. On the one hand, the nation "permits" the sovereign to exercise the general will. On the other hand, the sovereign "represents" the people.

As opposed to a holder of a mandate "who merely communicate[s] an already established will", the sovereign is a representative who is to "“form" this will" himself (Schmitt 1994, 140). Indeed, it may be that "a will of the people in terms of content is inexistent, and has to be formed by the representatives" (Schmitt 1994, 140). This relates to the content/decision dichotomy: the sovereign represents the "nation" in deciding on the content of the will, being justified in doing so by the pouvoir constituant. However, the question necessarily arises again as to whether a united "will of the people" exists. In addition, it must also be questioned whether the constitutive element of the "will of the people" (if this is indeed plausible) can exist without content; and further, whether that constitutive element constantly remains as a unity regardless of the fact that many (sometimes, even a majority) of the individual wills will have contents which significantly differ from that formed by the sovereign. This is crucial in the pluralistic modern society: it is one thing to relegate pluralism to being merely content-specific (as distinct from its "constituting element"); it is another thing to say that this general constituting will remains a unity even when the content of the will formed by the sovereign is tangential to the contents of the individual wills of the people.

The "permissibility" limb is postulated in contradistinction to a mandate, and hence it does not depend on a referendum. This is clear from the way Schmitt rejects Rousseau's use of the referendum to compare the "legislator's designs" against the "volonté générale", which for Schmitt $(1994,126)$ might present the inexplicable situation of a negative referendum: a going "against the law and the great soul". It is also necessary for Schmitt to reject the use of the referendum to avoid making "the people" an organ of the constitution in order to maintain the continuing relevance of the pouvoir constituant even in the absence of a normative order. However, Schmitt (1994, 141-142) does not then explain how this permissibility comes about, for he only mentions it in passing. This is surprising, since there surely must be a "permission" before the sovereign can "represent". In other words, "permissibility" is prior in relevance and importance to "representation" in the logical sequence of analysis. Without a referendum, the only alternative is for there to exist a concrete 
unity of will — one that binds every individual — so that it matters not which individual (or body of individuals) acts as the sovereign, since anybody would properly be permitted to act by everyone else. Unfortunately, as discussed above, this unity seems to be a mere fictitious presupposition. Hence, the criticism is made that the sovereign's decision "lacks an ethical moment" (Delacroix 2005, 31).

In counterargument, it could be said that the "permissibility" given to the sovereign in the state of exception derives not from the old constitution but from the future constitution. This idea that the sovereign "remains in functional dependence from an...imagined constitution" (Schmitt 1994, 146) runs like a thread throughout Schmitt's work. However, it appears to engage a retrospective fallacy. The doubt here concerns not the sovereign's actions, but the retrospective attribution of legality to it - a legality which is lacking at the very moment the sovereign makes his decision. Only with the benefit of hindsight can one properly claim that (to paraphrase Schmitt 1994, 133) "the negation of the immediately present state of affairs did allow for a more precise determination of the future state of affairs." Indeed, one must wait for the new normative order to be in place before one can tell if a particular state of affairs was an "exceptional transition" and not an "absolute monarchy" or a "sovereign aristocracy". This clearly reveals the fallacy in incorporating the "timelessness" of the omnipotent God into a time-bound secularised theory where time travels in a linear fashion.

\section{c) The decision and the discourse of the limits}

It seems to accord well with our instincts to say that what is "legal" is a norm; and thus when the normative order ceases to exist then what remains must be something "extra-legal". Indeed, many great jurists construct their theories upon this very premise. Schmitt, however, takes a unique approach: for him, a legal order consists of two distinct elements - "norm" and "decision". Since a legal idea (that is, a norm) "in its purity can never become reality", it requires a decision to make the norm concrete; and a decision cannot be derived from the legal idea or normative legal order (Schmitt 1985, 30). The distinctness of "norm" and "decision" is indubitable; but Schmitt $(1985,13)$ goes further by claiming that the decision "reveals a specifically juristic element...in absolute purity" in the exception. However, this last claim may be one too hastily made in his exposition. Granted that whatever we recognise as concretely "legal" may not consist exclusively of a norm; it still does not follow that the non-normative constituents may independently be "legal". In other words, a decision may be necessary for a concrete legal order to exist, but it does not follow that the decision is itself sufficient for it.

To emphasise the idea that "norm" and "decision" are irreducible elements, Schmitt (1985, 31-32) states that, "[l]ooked at normatively, the decision emanates from nothingness" (emphasis added). But Schmitt takes the decision to mean much more than "a non-norm". Delacroix $(2005,39-40)$ points out that "in überdie drei Arten, the decision is characterised as an "absolute beginning"". The elevation of the decision to this God-like position necessarily relegates the pouvoir constituant to 
being at most a quasi-justification; since if it did in fact justify (in the full sense) the decision of the sovereign, then "the people" (and not the sovereign) would be the true "absolute beginning".

What then does this absolute "point of ascription" rest upon? Derrida (1992, 14) suggests that a terminal point in legal analysis "can't by definition rest on anything but [itself]...[It is] neither legal nor illegal in [its] founding moment." This uncomfortable compromise reveals the difficulty in defining the limits of law as being occupied by a secular being or action. From a more optimistic point of view however, it could be said that, only if such an irresolvable dichotomy emerges can we say that we have reached the concrete apex within a secularised theory. But it surely does not preclude the possibility that there lies beyond it a transcendental being whose absolute being is the ultimate apex of legality. To use the terminology of Arendt (1998, $177 \mathrm{fn}$ 3), who draws from the work of Augustine, the sovereign's decision could well be the initium - "the beginning which is a man...inserted within the continuum of time"; but it certainly is not the principium — "the absolute beginning...that can only be the work of God" (discussed in Delacroix 2005, $40 \mathrm{fn} \mathrm{25).}$

A final issue must be addressed. The subject-matter the "absolute beginning" is clearly "the new normative order — the future constitution." Yet, the relationship between the decision and the new constitution is an uneasy one; and this has very much to do with the realm of time and space within which the secular operates. Schmitt clearly saw the decision as being "before" the new legal order, in the sense that it was "prior" to it. But this seems to ignore the need for the sovereign as well as his decision to be "in front of" the new legal order. As Davies (1996, 70-71) writes: "this linear positivist chronology in which pre-existing human beings create a legal system...neglects the various ways in which subjects appear after or in front of the law as its constructions". The same goes for Schmitt: how can the sovereign's "absolute" decision create a legal order which must recognise that decision itself as legal? Indeed, how can the people of the "nation" — which, as the constituting power, must by definition be extra-legal and not norm-bound - be subject to the new normative order? One might attempt to resolve the matter by drawing upon the theological concept of the revelation to say that the sovereign and the "nation" may reveal themselves to the new normative order, since they "could not be known apart from the unveiling" (Goswiller 1987, 3). Indeed, Schmitt $(1994,134)$ writes that "it is conceivable that the holder of state power puts himself into a dependence...from which he makes himself dependent, becoming constituted sovereign and without... cancelling all earthly power" (emphasis added). But yet again, a lacuna appears: for although the concept of the revelation may explain the transition between the state of exception and the new constitution - i.e. the subjecting of the decision to the new normative order - it nonetheless fails to explain why the sovereign and the people are necessarily bound by those norms, since any individual could opt out of the legal system on this view. It would seem that, unlike God, human beings and their actions in the secular realm are only confined to one or the other: either they are within the legal order, or they are without. 


\section{IV: CONCLUSION}

In conclusion, by shifting the focus away from the "comfortable superficiality" of the general to an inquiry based on the exception, Schmitt's theory undoubtedly opens up jurisprudential thought to novel approaches in defining the sovereign and the limits of law. Many of the conceptual "landmarks" of his theory — such as the distinction between norm and decision, and the purported secularisation of theological concepts - raise interesting and unique questions. However, as Delacroix $(2005,44)$ observes, "[t]he interest of Schmitt's theory...lies more in the issue it raises than in the answer it tries to provide." The crux of the problem, it seems, is the inherent dissonance between the transcendental and the temporal - the contradiction that exists when the attempt is made to "secularise theological concepts". In the words of the theologian Charles Spurgeon, "“"the proper study of mankind is man"...but...it is equally true that the proper study of God's elect is God" (quoted in Packer 1993, 17). Without an omnipotent God, Schmitt's attempt appears to fall short of overcoming the dialectics; and as such it does not provide a viable concrete account of the sovereign. However, if Schmitt's work is viewed not as the search for the ultimate legal limits but an attempt to discover the best possible theory within the confines of the secular, then perhaps his theory can be said to be viable. 


\section{References}

Arendt, Hannah. 1958. The Human Condition. $2^{\text {nd }}$ ed. Chicago, I.L. : University of Chicago Press.

Böckenförde, Ernst-Wolfgang. 1986. The Concept of the Political : A Key to Understanding Carl Schmitt's Constitutional Theory. In Law as Politics. Carl Schmitt's Critique of Liberalism. Ed. David Dyzenhaus, 37-55. Durham, N.C. : Duke University Press.

Davies, Margaret. 1996. Delimiting the Law. "Postmodernism" and the Politics of Law. London : Pluto Press.

Delacroix, Sylvie. 2005. Schmitt's Critique of Kelsenian Normativism. Ratio Juris 18: 30-45.

Derrida, Jacques. 1992. Force of Law: the "Mystical Foundation of Authority". In Deconstruction and the Possibility of Justice. Eds. Drucilla Cornell et al, 3-67. London : Routledge.

Goswiller, Richard. 1987. Revelation. Melbourne : Pacific Study Series.

Packer, James I. 1993. Knowing God. Downers Grove : InterVarsity Press.

Schmitt, Carl. 1928. Verfassungslehre. Munich : Duncker \& Humblot.

---- Schmitt, Carl. 1985. Political Theology. Four Chapters on the Concept of Sovereignty.

Cambridge, MA : MIT Press. (1 ${ }^{\text {st }}$ ed. In German 1922.)

--- Schmitt, Carl. 1994. Dictatorship. $6^{\text {th }}$ ed. Berlin : Duncker \& Humblot. $\left(1^{\text {st }}\right.$ ed. In German 1921.) 